\title{
外来患者数と調剤業務量との統計的考察*1
}

\author{
斎藤 弥, 宮家 淳 $* 2$, 岩崎由雄 $* 3$, \\ 亩京都済生会中央病院薬版部*2. \\ 東京六学医学部付属病院分院薬剤部*3.
}

\section{Statistical Study of the Number of Outpatients and Amount of Dispensing Service*1}

\author{
WATARU SAITo, ATSUSHI MIYAKE*2 \\ and YoSHIO IWASAKI*3
}

Department of Pharmacy, Tokyo-to Saiseikai Central Hospital*2

Department of Pharmacy, ToKyo University Branch Hospital*3

\begin{abstract}
Time series of the number of outpatients which may influence the number of outpatient prescriptions as an index to the amount of dispensing service at hospital pharmacy was analyzed on the basis of the 62-month survey. The influence was studied statistically. The influence rate (in terms of a square number of correlation coefficient) of the number of outpatients was $14.6 \%$ which was not satisfactory as a time series function. The rate of the number of prescriptions to the number of outpatients averaged $54.1 \%$. The monthly variation of the rate was not so large. The influence rate of the number of outpatients to the number of outpatient prescriptions was as high as $62.1 \%$, indicating considerable effect of the number of patients on the amount of dispensing service.
\end{abstract}

\section{はじめに}

病院薬局における調剤業務管理資料として,第 1 報 ${ }^{11}$, 第 2 報 ${ }^{2}$ において処方せん枚数，処方件数および剤数に ついて各データの推移, 月別変動值および最小 2 乗法を 用いて回帰方程式を求めて統計学的解析の結果を報告し た. 今回, 調剂業務量の指標としての外来処方せん枚数 に影響を拉よぼしていると考えられる外来患者数につい て，時系列解析扣よび外来患者数の処方せん枚数におよ ぼす影響について統計学的考察を行った。

\section{方法}

1971 年 1 月より1976 年 2 月まで 62 力月間につき, 外来患者数については病院統計資料にもとついた值を使 用し，外来処方せん枚数は前回 ${ }^{1,2)}$ までの值を用いた. なお,統計解析には前報 ${ }^{2)}$ の結果より外来患者数, 外来処

*1 本報を調剤業務の管理学的検討（第 3 報）とする.

*2 東京都港区三田 1 丁目4-17 ; 4-17, Mita 1-chome, Minato-ku, Tokyo, 108 Japan

*3 東京都文京区目白台 3 丁目28-6 ; 28-6, Medirodai 3-chome, Bunkyo-ku, Tokyo, 112 Japan
方せん枚数共に実働日数で除した 1 日平均数をもとめて 行った. 統計解析方法としては, 12 力月移動平均値 ${ }^{3)}$, 対傾向値比率法による月別変動値 ${ }^{4}$, 最小 2 乗法による 回帰方程式 $3,5,6)$, 相関係数検定 ${ }^{3,5)}$, 寄与率 3,6$)$, 変動係 数王), 分散分析 ${ }^{3,5)}$, 前年同月比 ${ }^{77}, 95 \%$ 信頼限界 ${ }^{3,5)}, お$ よび残差の検討らなどの統計的手法を試みた.

\section{結}

\section{1. 外来患者数における12力 月移動平均值と回带方程 式}

外来患者数の 12 力月移動平均值之回帰方程式は図 1 の ごとく, 12力月移動平均值は1972 年11 月まで減少を示 したが，その後増加の傾向を示した．移動平均值の最 小值は 1972 年10月, 11 月の 788 , 最大值は 1975 年 3 月, 4 月の 882 , その差 104 であった。 また, 各月データの 增減が激しく, 移動平均值の一様な变化を示すグラフと. はならなかった. 回齊方程式は

$$
\mathrm{y}=788.134+1.276 \mathrm{x}
$$

で62力月間の推移は77.8の增加であった。

2. 外来㭧者数および外来処方せん枚数での時系列解 


\section{析の比較}

\section{2-1. 移功平均值}

外来患者数と外来処方せん枚数の 12 力月移動平均值の 比較は図 2 のごとく，処方せん枚数についてはほぼ漸次
増加の傾向があることを第 1 報で報告したが，外来患者 数は1973 年まで大きく減少し，その後增加の傾向を示 した.

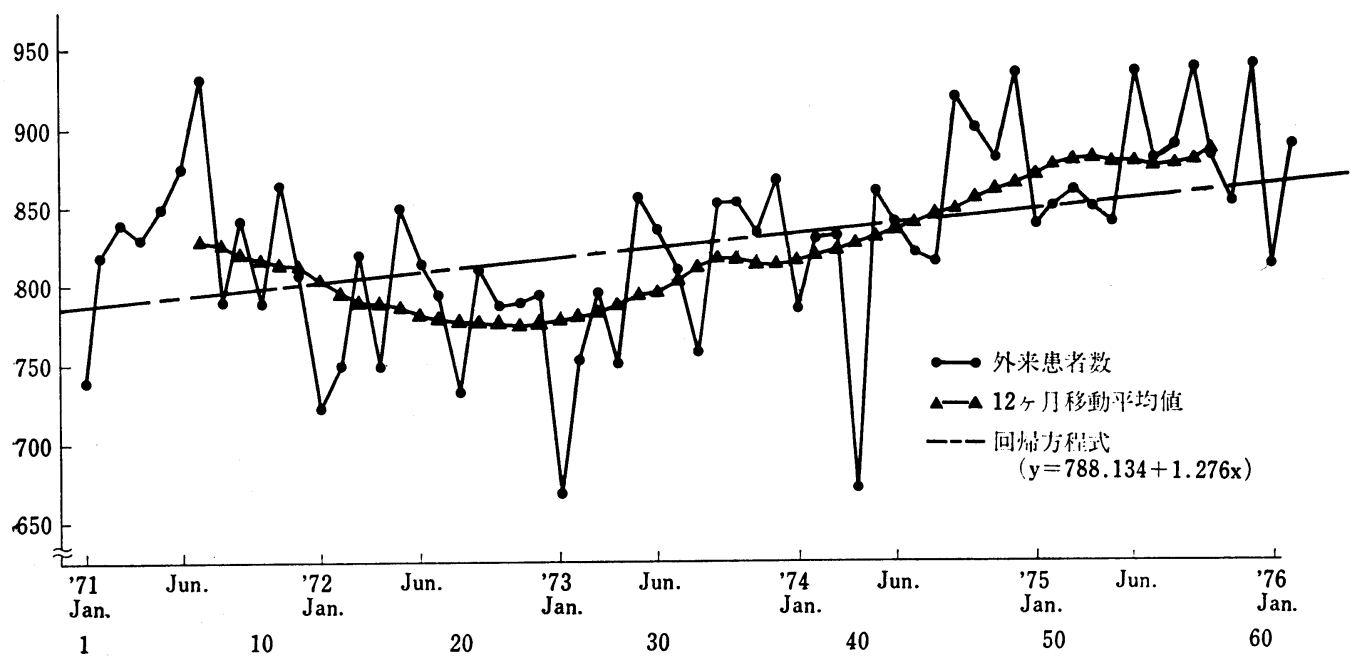

図 1. 外来患者数の 12 力月移動平均值と回㷌方程式

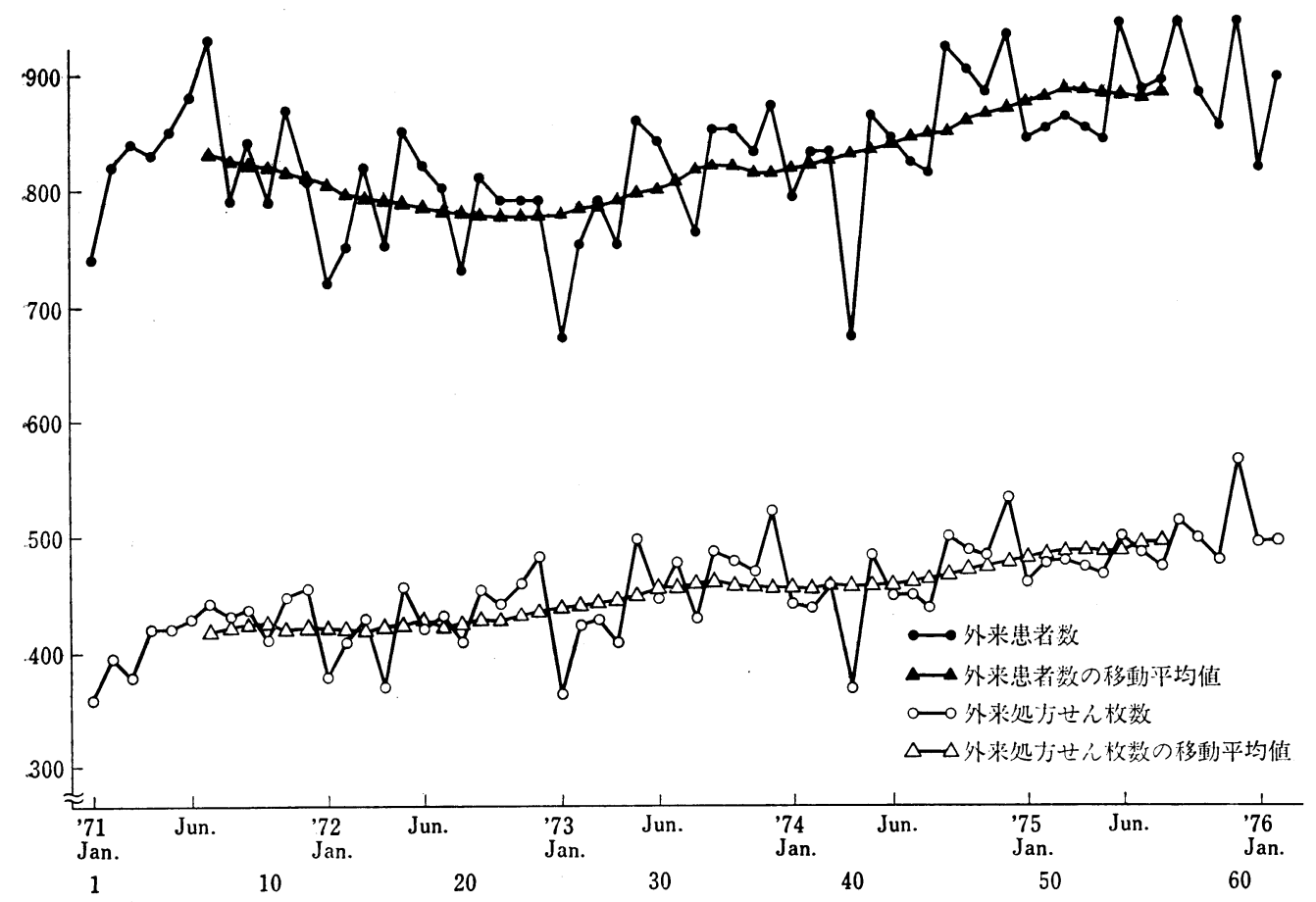

図 2 . 外来患者数と外来処方せん枚数の 12 力月移動平均値 
外来患者数と外来処方せん枚数の相関係数検定および 回帰式検定の比較は表 1 に示すごとく, 相関係数検定, 回帰式検定共に危険率 $1 \%(\alpha=0.01)$ で有 意であっ た. 寄与率は処方せん枚数 $\mathrm{r}^{2}=0.470$ に対して患者数 $\mathbf{r}^{2}=0.146$ であり，また，回帰方程式の勾配は処方せん
枚数の1.581に対して1.276であった．分散比では処方せ ん枚数 $\mathrm{F}_{0}=52.28$ に対して $\mathrm{F}_{0}=10.26$ であり, 全体の変 動係数值は処方せん枚数の $\mathrm{T}_{\mathrm{c}}=0.075$ に対して患者数の $\mathrm{T}_{\mathrm{c}}=0.230$ で, これらの結果は外来患者数が外来処方せ ん枚数に比べてバラッキの大きい結果を示した.

表 1 . 外来患者数と外来処方せん枚数の相関係数検定と回帰式検定

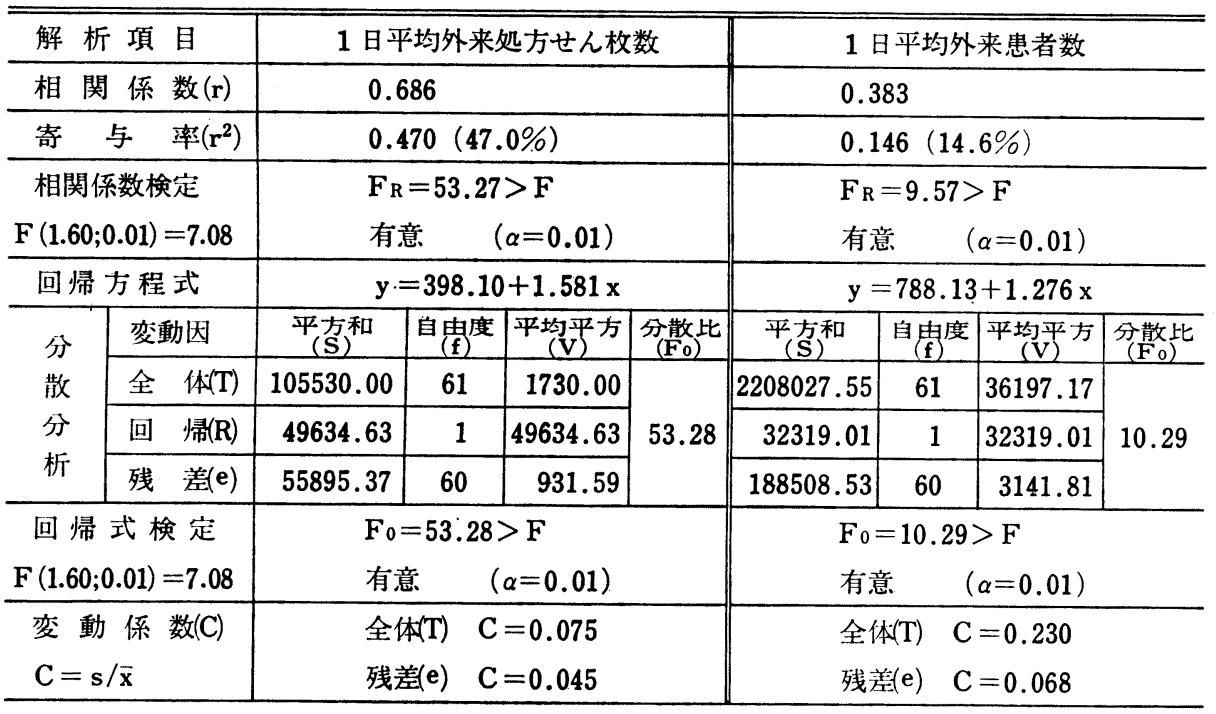

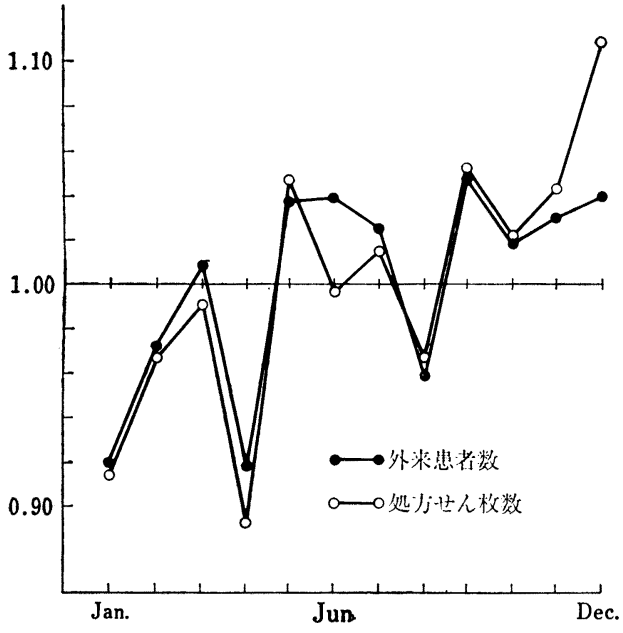

図 3. 外来患者数と外来処方せん枚数の月別変 動值

\section{2-3. 月别変功值}

外来患者数と外来処方せん枚数の月別変動值の比較は 図 3 のごとく，患者数は 6 月の 1.038 に対して処方せん 枚数の 0.996 ，また12月の 1.038 に対して 1.108 であっ た。その他の月はほぼ同様な変化を示した.

\section{2-4. 前年同月比}

外来患者数と外来処方せん枚数の前年同月比の比較は 図 4 のごとく，処方せん枚数は患者数に比べて大部分 1.00 以上にあり, 漸次増加の傾向を示した。 ピークは 1974 年と 1975 年度 4 月の同月比, 患者数の 1.268 , 処方 せん枚数の 1.282 であり, 最小值は患者数では 1971 年 と 1972 年度 7 月の同月比 0.853 , 処方せん枚数では同年 5 月の同月比 0.882 であった。

\section{3. 外来患者数の外来処方せん枚数におよぼす影㽝に ついて}

\section{3-1. 外来蝟者数に対する外来処方せん枚数の各月に} おける割合と移動平均値

外来患者数に対する外来処方せん枚数の, 各月の割合 に関する時系列值と移動平均值は図 5 のごとく, 各月の 割合については, 最小值は1971年 3 月 $44.8 \%$, 最大值は 1972 年11月 $62.0 \%$ であり, 62 力月間の平均值は $54.1 \%$ であった.この割合を時系列関数として12力月移動平均 值を求めると，1973年まではかなりの増加を示したが, その後1974年 7 月まで減少し再び増加の傾向を示した.

\section{3-2. 月别変功值}

外来患者数に対する外来処方せん枚数の割合を, 時系 列関数とした月別変動值は図 6 のごとく，4月と 6 月の 


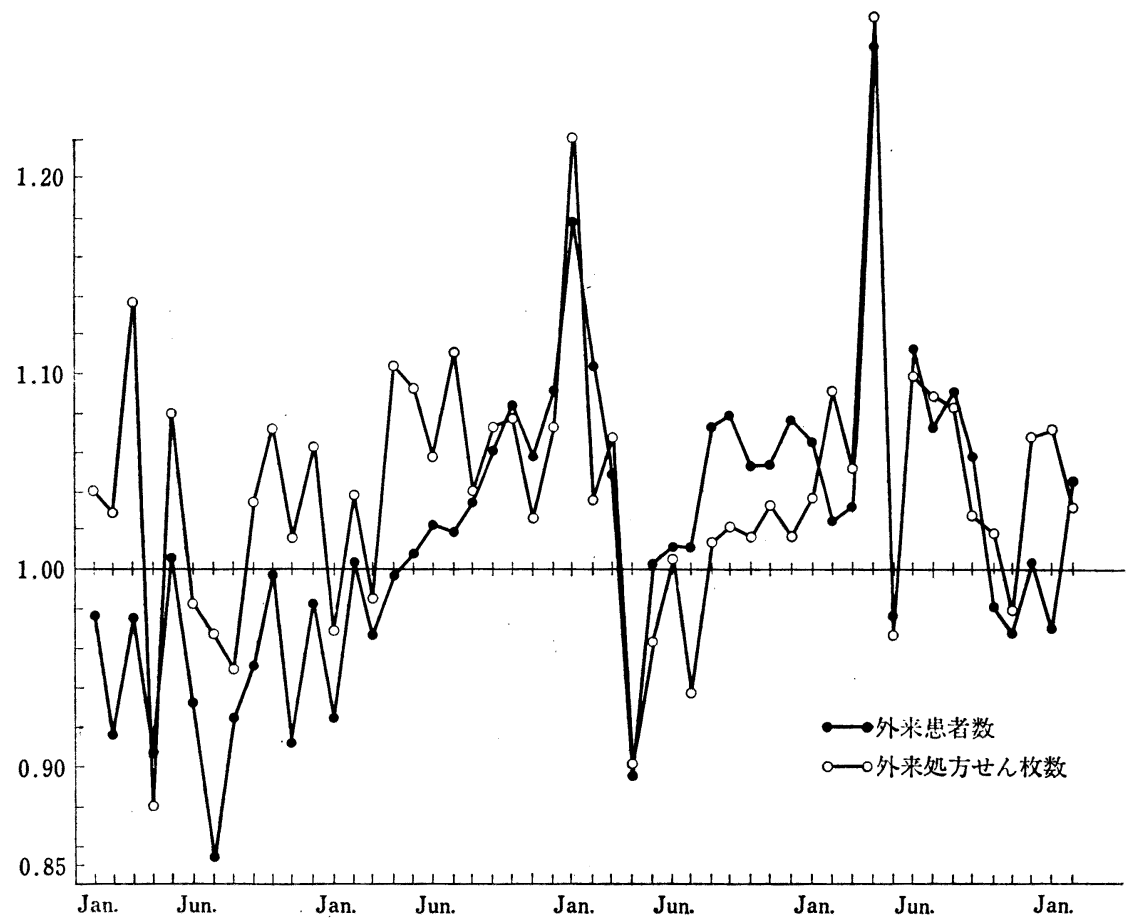

図 4. 外来患者数と外来処方せん枚数の前年同月比

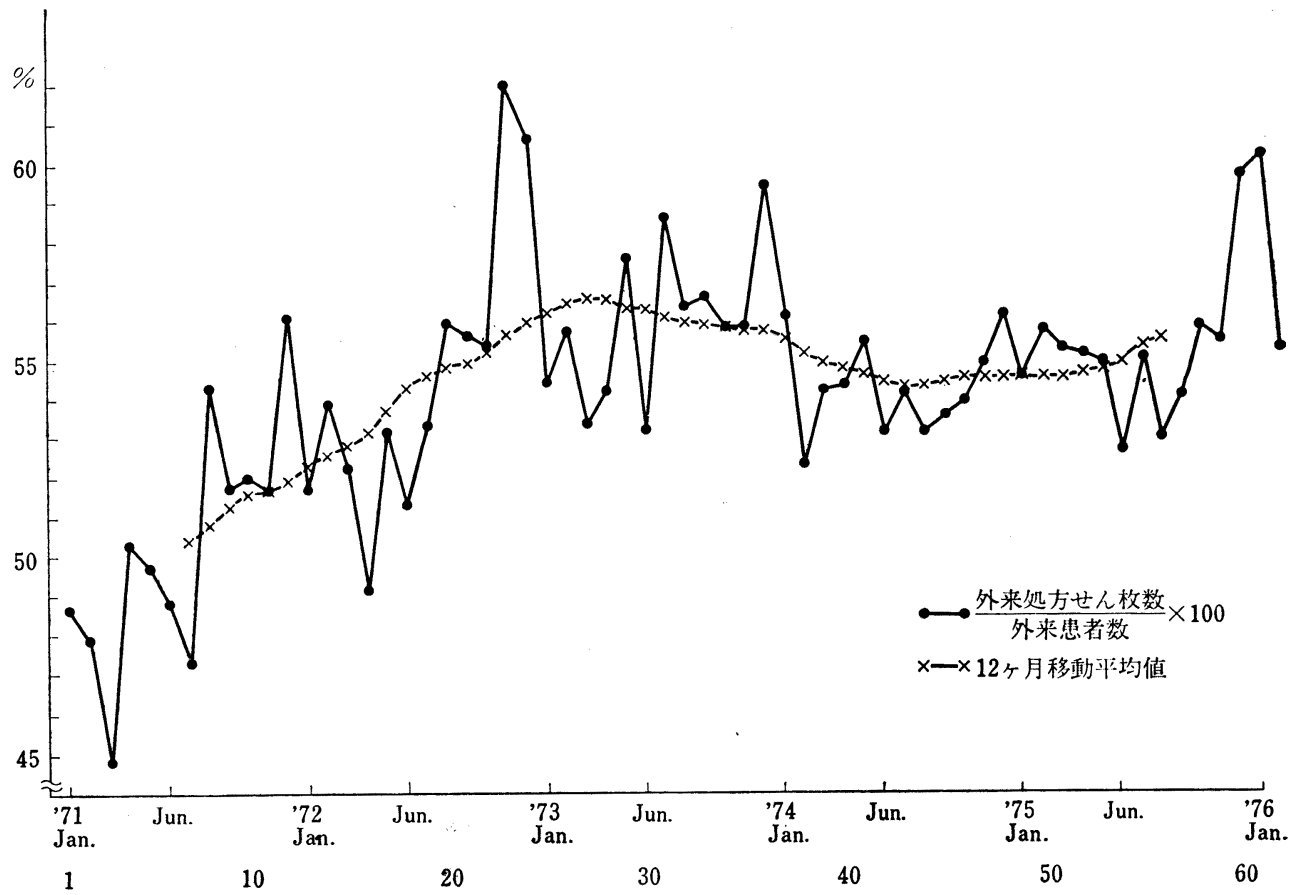

図 5. 外来思者数に対する外来処方せん枚数の各月の割合と 12 月移動平均值 
减少 (最小值は 6 月0.956), 11 月と 12 月の增加（最大値 は12月 1.065）であったが余り大きな变化は示さなかっ た。

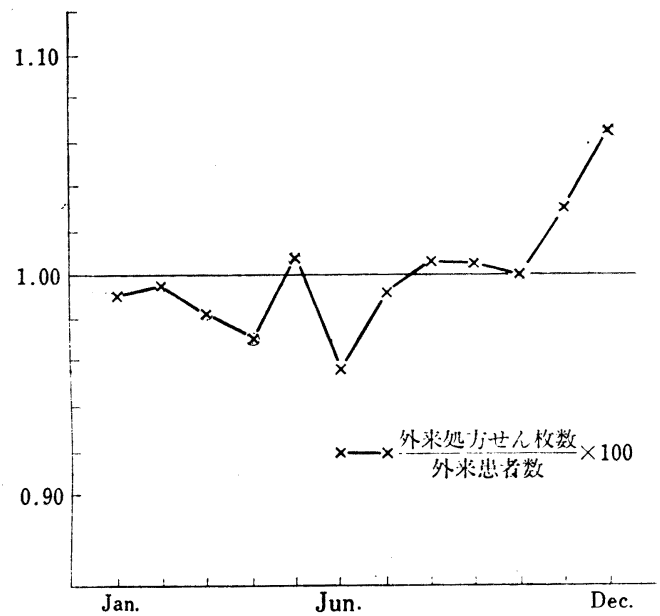

図 6. 外来患者数に対す万外来処方せん枚数の 各月の割合についての月別変動值

\section{3-3. 回为方程式と $95 \%$ 位賴限界}

横軸に外来患者数を, 綎軸に外来処方せん枚数の值を プロットすると，その回帰方程式と $95 \%$ 信頼限界は図 7
のごとく, 回㷌方程式は

$$
\mathrm{y}=-3.187+0.544 \mathrm{x}
$$

であり，また勾配 0.544 の㑑は，患者数に対する処方せ ん枚数の各月に拈ける割合の平均值 0.541 とほぼ同值と

表 2. 表外来患者数と外来処方せん枚数の相関性につ いて（相関保数検定と回帰式検定）

\begin{tabular}{|c|c|c|c|c|c|}
\hline \multicolumn{2}{|c|}{ 解 析 項 目 } & \multicolumn{4}{|c|}{ 処方せん枚数と患者数の相関関係 } \\
\hline \multicolumn{2}{|c|}{ 相 関 係 数 $(\mathbf{r})$} & \multicolumn{4}{|c|}{0.788} \\
\hline \multicolumn{2}{|c|}{ 寄 与 率 $\left(\mathrm{r}^{2}\right)$} & \multicolumn{4}{|c|}{0.621} \\
\hline \multirow{2}{*}{\multicolumn{2}{|c|}{$\begin{array}{l}\text { 相関係数検定 } \\
F(1,60 ; 0.01)=7.08\end{array}$}} & \multicolumn{4}{|c|}{$F_{R}=98.14>F$} \\
\hline & & 有意 & $(\alpha=$ & $0.01)$ & \\
\hline \multicolumn{2}{|c|}{ 回㷌方程式 } & \multicolumn{4}{|c|}{$\mathrm{y}=-3.187+0.544 \mathrm{x}$} \\
\hline \multirow{2}{*}{$\begin{array}{l}\text { 分 } \\
\text { 散 }\end{array}$} & 変動因 & $\begin{array}{l}\text { 平方和 } \\
(\mathrm{S})\end{array}$ & 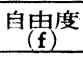 & $\begin{array}{c}\text { 平均平方 } \\
\text { (V) }\end{array}$ & $\begin{array}{l}\text { 分散比 } \\
\left(\mathbf{F}_{0}\right)\end{array}$ \\
\hline & 全 体(T) & 105529.42 & 61 & 1729.99 & \multirow{3}{*}{98.14} \\
\hline \multirow{2}{*}{$\begin{array}{l}\text { 分 } \\
\text { 析 }\end{array}$} & 回 帰(R) & 65489.89 & 1 & 65489.89 & \\
\hline & 残 差(e) & 40039.53 & 60 & 667.33 & \\
\hline
\end{tabular}

\begin{tabular}{l|ll}
\hline 回 帰 検 定 & \multicolumn{2}{|l}{$\mathrm{F}_{0}=98.14>\mathrm{F}$} \\
$\mathrm{F}(1,60 ; 0.01)=7.08$ & 有意 $\quad(\alpha=0.01)$ \\
\hline 変 動 係 数(C) & $\begin{array}{l}\text { 全体 }(\mathrm{T}) \\
\mathrm{C}=\mathrm{C} / \overline{\mathrm{x}}=0.093\end{array}$ \\
\hline
\end{tabular}

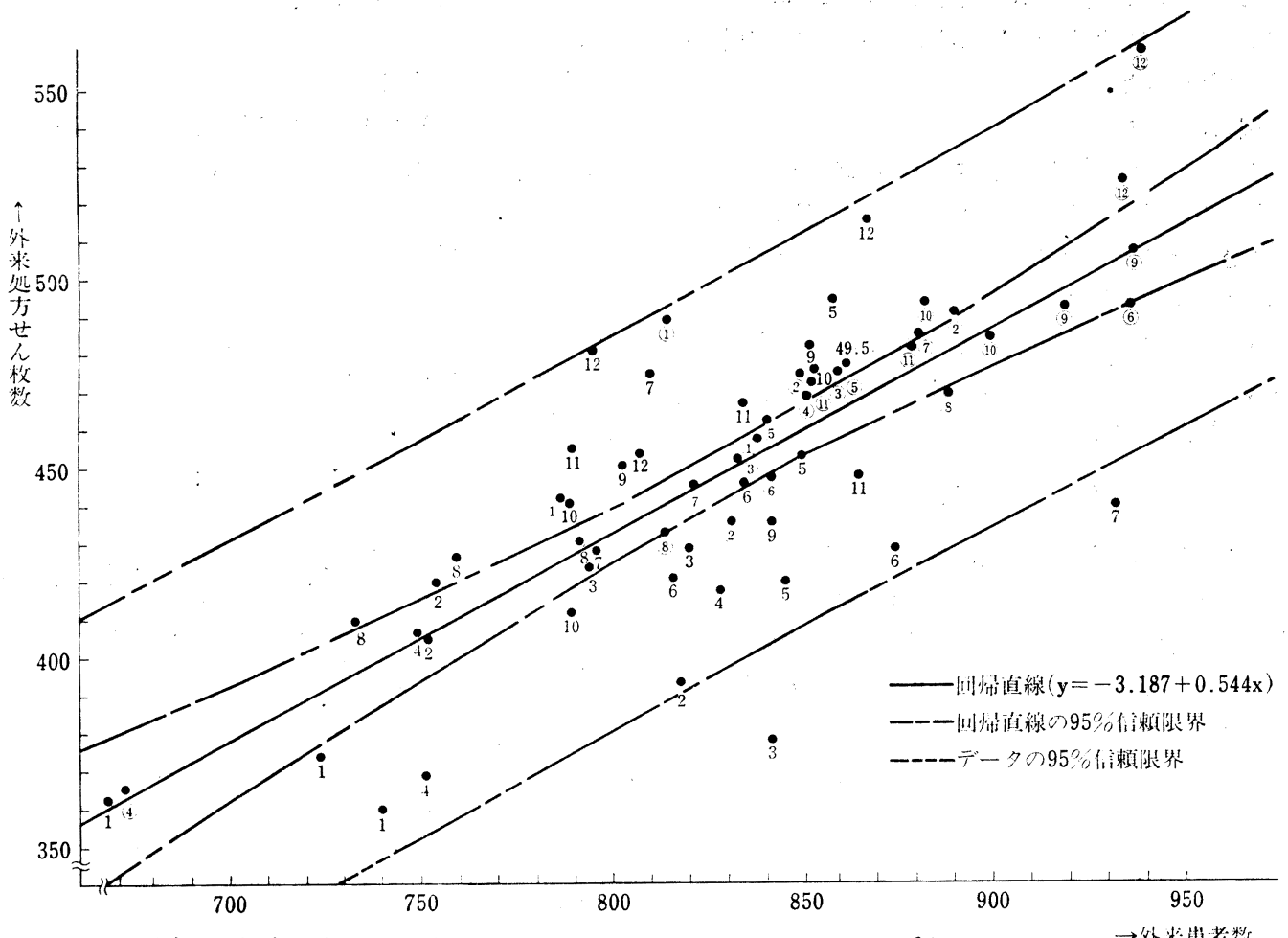

図 7 . 外来患者数と外来処方せん枚数に関する回㷌方程式と $95 \%$ 信頼限界 


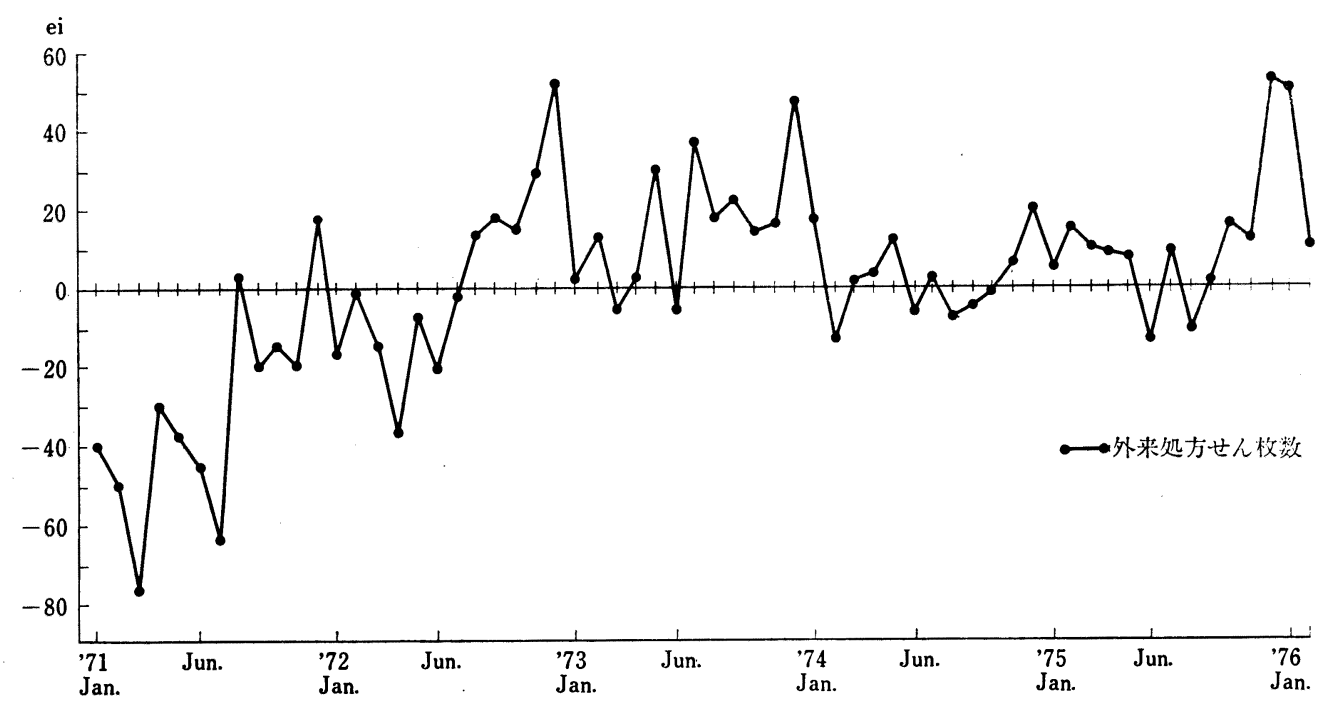

図 8. 回㴆式に対する外来患者数よりみた外来処方せん枚数の残差の検討

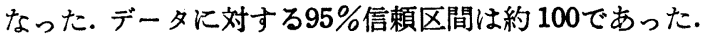

\section{3-4. 相間係数亡回需榙定}

外来患者数の，外来処方せん枚数に対する相咸性につ いての相関係数検定と回帰式検定の結果は表 2 のごと く, 相関係数検定および回帰式検定は危険率 $1 \%$ （ $\alpha=$ 0.01）で共に有意であった，相関係数 $r=0.788$, 寄与 率 $\mathrm{r}^{2}=0.621$, 分散比 $\mathrm{F}_{0}=98.14$ となりバラッキのある データではなかった。

\section{3-5. 残竸の模㣙}

回帰方程式に対する外来患者数よりみた外来処方せん 枚数の残差の検討は図 8 のごとく，1971年 1 月より 1972 年 7 月まではマイナス值であったが, 1973年にかけプラ ス値となり，1972年12月の52.4をピークにして，1974年 から1975年11月までは余り変化を示さなかったが, 1975 年 12 月と 1976 年 1 月に再びピークとなった. このグラ フより特に傾向は示されなかった。

\section{考察}

以上の結果から, 外来患者数は外来処方せん枚数に比 ベてバラッキが大きく，一様な推移を示さなかった．ま た, 外来患者数では寄与率 $\mathrm{r}^{2}=0.146$ で時系列関数とし てはよいデータとはいえなかった．62力月間の長期間時 系列解析を行ったために相関係数検定, 回帰式検定は危 険率 $1 \%(\alpha=0.01)$ で共に有意となったが，今後，外 来患者数の予测をする場合, 調査期間前半の減少部分を 削除し，一様な推移を示す時点以降のデータを用いて回 帰方程式を求める必要があると考える.

外来患者数に対する外来処方せん枚数の各月に打ける
割合の平均值は 54. 11\% であり,外来患者の半数以上に 処方せんが交付されていた。 その割合は一時期減少して いるが再び増加の傾向を示し, 今後ある程度まで增加す るものと考える. 月别変動値については,わずかに外来患 者数に対する外来処方せん枚数の各月の割合について変 化がみられたが，月別に変化のあるものとはいえなかっ た.

外来患者数と外来処方せん枚数の相関性について, 寄 与率は $62.1 \%$ となり患者数の増減が処方せん枚数に対 してかなりの影響（62.1\%）をおよぼしているものと考 えられる.

今後の課題として, 調剤業務量の予測について外来患 者数の推移とそれに伴う外来処方せん枚数の予測につい て，また，今回まで報告した処方せん枚数，処方件数抒 よび斉数に関する相関性について統計的考察を行ってみ たいと考えている.

\section{文塥}

1) 斎藤 弥, 宮家 淳, 岩崎由雄 : 調剂業務の管理 学的検討(第 1 報), 病院薬学, 2 (4), 232 (1977).

2) 斎藤 弥, 宮家 淳, 岩崎由雄 : 調剤業務の管理 学的検討(第 2 報): 病院薬学, 3(2), 110 (1977).

3）実務教育研究所 : 現代統計実務講座, II, 実務教 育研究所 (1977).

4）竹内 清 : 需要予測入門, 丸善, (1974).

5）小林龍一：相関-回㷌分析法入門，日科技連, (1975).

6）松島康夫, 江副 力：OR手法とその応用，オー 么社, (1976).

7) I.C.I. Monograph 2 : 短期予测方式, 培風館 (1972). 